\title{
REVIEW OF PLANTS USED AS KSHAR OF FAMILY PIPERACEAE
}

\author{
Gupta $\mathrm{V}^{*}$, Meena $\mathrm{AK}^{1}$, Krishna $\mathrm{CM}^{3}$, Rao $\mathrm{MM}^{1}$, Sannd ${ }^{1}$, Singh $\mathrm{H}^{1}$, \\ Panda $\mathrm{P}^{1}$, Padhi $\mathrm{MM}^{2}$ and Ramesh $\mathrm{Babu}^{2}$ \\ ${ }^{I}$ National Institute of Ayurvedic Pharmaceutical Research, Patiala-147001, Punjab \\ ${ }^{2}$ Central Council for Research in Ayurveda and Siddha, Janakpuri, Delhi-110058 \\ ${ }^{3}$ National Institute of Indian Medical Heritage, Hyderabad, India
}

\begin{abstract}
Many herbal remedies individually or in combination have been recommended in various medical treatises for the cure of different diseases. Kshara is a kind of medication described in Ayurveda Texts for the management of various disorders. The genus Piper L. is estimated to contain over 1000 species which are distributed mainly in tropical regions of the world. This review mainly focuses on the plants of family Piperaceae that are used in Kshar so that more research work is carried out in the direction of standardization, therapeutic level determination of Kshar plants.
\end{abstract}

Keywords: Kshar, Piper, Piperaceae, Herbal remedies

\section{INTRODUCTION}

The word Kshara is derived from the root Kshar, means to melt away or to perish. Acharya Sushruta defines as the material which destroys or cleans the excessive/the morbid doshas (Kshyaranat Kshyananat va Kshara). According to the preparation we can consider it to be caustic materials, obtained from the ashes after distillation and are mostly alkaline in nature.

According to the administration it is of two types

1. Paniya Kshara (for internal Medication)

2. Pratisaraniya Kshara (external application)

The Paniya Kshara is mostly used for the treatment of diseases like artificial poison, abdominal lump, indigestion, calculus etc. The Pratisaraniya Ksara is used to apply on tumors, piles, fistula in ano, skin diseases etc (Shukla et al. 1994, Sharma et al. 1995)

\footnotetext{
* Corresponding Author:

Vikas Gupta, National Institute of Ayurvedic Pharmaceutical Research, Patiala, India. E-Mail: vikas_4308@rediffmail.com Tel: 09914933022
}

\section{Drug Used}

Many drugs have been advised by Sushruta and other Ayurvedic texts for the preparation of Kshara (Ghanekar 1998, Sharma et al. 1995)

\section{Method of Preparation}

According to the three types of Ksharas are prepared on the basis of their strength. Mild - Mridu, Moderate Madhyama, Strong - Tikshna

The general procedure can be narrated as - 'Mridu' Bhașmīkaraņa (conversion to ash) Adding to water (1:6 ratio) Filtration (21 times) Distillation (boiling the ksarajala still all water evaporates) collection (process called lixiviation) 'Madhyama' Here the procedure is same some extra powders of Katasarkara Bhasma sarkara Ksheerapaka, Samkhanabhi( gravels of lime and ash,oyester-shell \& core of conch-shell) are added to the boiling ksharajala before distilling it. 'Tikshna' Similar to madhyama kshara here added is the powders of drugs like Chitraka, danti, vacha etc. inplace of the lime stones (Ghanekar 1998, Shukla et al. 1994, Sharma et al. 1995). 


\section{Family- Piperaceae}

The genus Piper L. is estimated to contain over 1000 species which are distributed mainly in tropical regions of the world. Several species have great economic and cultural importance and are used as foods, medicines, stimulants, antiseptics and antioxidants (Arunrat et al. 2006). There are three important plants used in Kshar Sutra from family piperaceae are $P$. nigrum Linn., Piper cubeba Linn., Piper longum Linn. (Kirtikar and Basu, 1935; Warrier et al. 2006; Yoganarasimhan and Chelladuri 2000)

\section{P. nigrum Linn.}

$P$. nigrum is the most important cultivated species due to its economic value (Bhat et al., 1995). Geographically, it is confined to Western-Ghats of South India (Nair et al., 2003). However, some reports of cultivation from Malaysia, Indonesia, Brazil, Sri-Lanka and West Indies are also available (Backer et al., 1963). P. nigrum had been found in vast altitudinal regions and showed great adaptability to a wide range of environmental conditions which led to inter-species diversity (Howard, 1973). "Black-pepper" as its generalized name is due to the colour of the peppercorn. It is considered as the "king of spices" due to its trade in the international market (Srinivasan, 2007; Mathew et al., 2001). Black-pepper is widely used in cooking and processing of food and perfumery (Philip et al., 1992; Bhat et al., 1995). Its quality is judged by its odour and pungency (Kay, 1970). Piperine is an active component in $P$. nigrum and contributes to its pungency (Tripathi et al. 1996). P. nigrum is reputed in the local system of medicine of India, Latin America and West-Indies for its multidimensional medicinal properties (Scott et al., 2008). Secondary metabolites from $P$. nigrum play defensive role against infections by microbes, insects and animals (Lupina and Crrips, 1987). Efforts have been made in screening these chemicals against different pathogenic species of microorganisms (Umit et al., 2009). Piperamides extracted from $P$. nigrum had shown insecticidal activities (Scott et al., 2005; Boff et al., 2006). $\beta$ caryophyllene extracted from $P$. nigrum showed anesthetic activity (Santra et al., 2005). Nerolidol is a very famous secondary metabolite of $P$. nigrum, used to control mites. Another important component of pepper volatile oil is pipene, which is a famous odorants (Jayalekshmy et al., 2003). Black-pepper is antimicrobial (Dorman and Deans, 2000), antimutagenic (EI-Hamas et al., 2003), a freeradical scavenger (Gulcin, 2005; Saxena et al., 2007), immuno-modulator, anti-tumor (Sunila and Kuttan, 2004), anti-depressant (Lee et al., 2005), anti-apoptotic (Pathak and Khandelwal, 2007), anti-metastatic (Pradeep and Kuttan, 2002), anti-thyroid (Panda and Kar, 2003), hepatoprotective (Koul and Kapil, 1993), immunostimulator (Pathak and Khandelwal, 2009), antidiarrheal and anti-spasmodic (Bajad et al., 2001). Black-pepper was reported to treat pulmonary diseases (Ravindran, 2000), fever, cold, colic disorder and gastric conditions (Parmar et al., 1997: Kumar et al., 2007). Recently, anti-spermatogenic and infertility effect in mice were reported by Mishra and Singh (2009). The following biologically important phytochemicals have been extracted from $P$. nigrum plants: alkaloids, amides, propenyphenols, lignans, neolignans, terpenes, steroid, kawapyrones, piperolides, chalcones, dihydrochalcones, brachyamide (Kiuchi et al., 1988), dihydropipericide (Miyakado et al., 1980), 3,4-dihydroxy-6(N-ethyamine), benzamide (Bandyopadhyay et al., 1990), (2E , 4E)Neicosadienoyl pereridine (Kiuchi et al., 1988), N-transferuloyltryamine, Nformylpiperidine (Stohr et al., 2001), guineensine (Kiuchi et al., 1988), (2E , 4E)-N-5[(4- Hydroxyphenyle)pentadienoyl] piperidine, (2E,4E)Nisobutyldecadienamide), (2E,4E)-Nisobutyleicosadienamide (Bano et al., 
1991), (2E,4E,8Z)-Nisobutyleicosatrienamide, $(2 \mathrm{E}, 4 \mathrm{E})-$ Nisobutyloctadienamide (Nakatani et al., 1980), piperamide, piperamine (Kiuchi et al., 1988), piperettine (Orjala et al., 2003), pipericide (Miyakado et al., 1980), piperine, piperolein, trichostachine, sarmentine, sarmentosine, tricholein, retrofractamide (Kiuchi et al., 1988). Concentration of alkaloids in fruits of $P$. nigrum ranges from 4 to $5 \%$ (Dev and Koul, 1997). Pino et al., 2003 observed that the major components of the essential oil obtained from the aerial parts of $P$. nigrum were gluulol, _-pinene, caryophyllene and _terpinene. Piperine was the first amide to be isolated from piper species. Piperine the major active principle of black pepper, is closely related in structure to the known natural carcinogens-safrole, estragole and methylengenol which are also widely distributed in spices and plant oils (Ames, 1983).

\section{Piper cubeba Linn.}

Piper cubeba (in Indonesia known as kemukus), is a plant, native to Java and Borneo that produces spicy berries (cubeb berries). It is now also cultivated in several other tropical areas, including East Africa. In Indonesia $P$. cubeba is valued as a medicinal plant (Eisei 1995, Sastroamidjojo, 2001). Only three groups of secondary metabolites have been reported from the berries of $P$. cubeba, i.e. alkaloids, lignans and terpenoids (essential oil). The lignans and the essential oil have been more intensively investigated, since $P$. cubeba accumulates both groups of compounds in relatively high amounts. Economically, $P$. cubeba is important as a source of pepper (the dried berries) for the worldwide spice market (Usia et al., 2005 $\mathrm{a}, \mathrm{b})$. Piperine is an abundant alkaloid in the berries of this species (Parmar et al., 1997). Twenty four lignans have so far been reported from P. cubeba (Prabhu and Mulchandani, 1985, Badheka et al., 1986, 1987, Koul et al., 1996, Parmar et al., 1997, Usia et al,. 2005). Lignans are an important group of secondary metabolites that are also assumed to contribute to the biological activity. Some of these lignans showed inhibitory activity against cytochrome P450 enzymes that are involved in the metabolism of all currently used drugs (Usia et al., 2005a, 2005b). Yatein, hinokinin, cubebin, dihydrocubebin have been reported to have antifeedant activity against a number of stored product insects. This activity is comparable to podophyllotoxin (Harmatha and Nawrot, 2002). Hinokinin has been reported to have anti-inflammatory and analgesic effect. Because of the structural relationship, hinokinin can be synthesized using cubebin as precursor (Da Silva et al. 2005). Cubebin has been shown to possess anti-inflamatory, analgesic and trypanocidal activities (Borsato et al., 2000, Bastos et al., 2001, De Souza et al., 2005). Yatein is also an interesting lignan due to its biological activity and its function as a biosynthetic precursor of deoxypodophyllotoxin and podophyllotoxin that are well known for their anticancer properties. Methanol and water extract of $P$. cubeba berries have been shown to display an inhibitory effect against the hepatitis $\mathrm{C}$ virus (Hussein et al., 2000). Anti-inflammatory, antioxidant, anti-allergic and analgesic activities of $P$. cubeba have been studied using chemically-induced edema and arthritis in vivo (Choi and Hwang, 2003 and 2005).

\section{Piper longum Linn.}

Piper longum Linn. is the accepted source of the drugs Pippali and Pippalimulam throughout the country. Pippali is the dried ripe fruits; Pippalimulam is the roots of this plant (Sivarajan \& Balachandran, 1994). The plant is a dioecious slender aromatic climber with perennial woody roots, or a perennial creeping under shrub. Branchlets erect, glabrous with swollen nodes; roots clasping at nodes, which help to get attached to the host trees; leaves alternate, ovate, cordate, apex acute to acuminate, margin entire, glabrous. The male and 
female plants are morphologically very similar till the formation of spikes. Mature female spikes, known as long pepper are shorter and thicker than the male spikes. Fruit spikes cylindrical, oblong, berries red or black when ripe, globose with aromatic odour and pungent taste (Sumy et al, 2000; Banerjee et al, 1999; Viswanathan, 1995, Sumy et al, 2000; Sivarajan \& Balachandran, 1994). The fruits contain $1 \%$ volatile oil, resin, alkaloids piperine and piperlonguminine, a waxy alkaloid $\mathrm{N}$ - isobutyldeca-trans-2trans-4-dienamide and a terpenoid substance. The pungency of the fruits is mainly due to the piperidine alkaloid piperine. The fruits also contain calcium, 1230; phosphorous, 190; and iron, $62.1 \mathrm{mg} / 100 \mathrm{~g}$. Roots contain piperine, piperlongumine or piplartine and dihydrostigmasterol (Neelam \& Krishnaswamy, 2001). This plant shows different pharmacological activity like antibacterial activity (Reddy et al, 2001), Antiallergic activity (Chatterjee, 1999; Dahanukar et al, 1984 ; Amit et al, 2003), Antitumour activity (Bai \& Xu, 2000; Sunila \& Kuttan, 2004), antitubercular activity (Kurup et al, 1979), Antifertility activity (Kholkute et al, 1979), vasodilating activity (Shoji et al, 1986), antigiardial and immuno-stimulatory activity (Tripathi et al, 1999). This plant is also used in treatment of intestinal disorders (Ghoshal et al, 1996), hepatoprotective effect (Koul \& Kapil, 1993), chronic bronchitis, cough and cold (Sumy et al, 2000) and bronchial asthma in children (Dahanukar et al, 1984; Anshuman et al, 1984).

\section{CONCLUSION}

Major thrust by whole of the pharmaceutical industry is focused towards design and development of new innovative/indigenous plant based drugs through investigation of leads from traditional system of medicine. In recent years, ethno-botanical and traditional uses of natural compounds, especially of plant origin received much attention as they are well tested for their efficacy and generally believed to be safe for human use. It is best classical approach in the search of new molecules for management of various diseases. Thorough screening of literature available on different species of family piperaceae depicted the fact that it is a popular remedy among the various ethnic groups, Ayurvedic and traditional practitioners for treatment of ailments. Researchers are exploring the therapeutic potential of these plants as it has more therapeutic properties which are not known.

\section{REFERENCES}

1. Bhat SR, Chandel KPS, Malik SK (1995). Plant regeneration from various expalnts of culyivated Piper species. Plant Cell Rep. 14: 398- 402.

2. Backer CA, Bakhuizen van den Brink RC. (1963). Flora of Java. I. Groningen, Noordhoff.

3. Arunrat C, Runglawan S, Tawatchai T, Piya M, Three new species of Piperaceae from Thailand, Acta Phytotaxonomica Sinica, 2006, 44 (4): 447-453.

4. Nair RR, Gupta SD (2003). Somatic embryogenesis and plant regeneration in black pepper (Piper nigrum L.). J. Hortic. Sci. Biotchnol. 78: 416-421.

5. Howard RA (1973). Notes on the Piperaceae of Lesser Antilles. J. Arnold Arb 54: 377-411.

6. Shukla, N.K. Narang, R. Nair, N.G.K., Radhakrishna, S., Satyavati, G.V.: Multicentric randomized controlled clinical studies of Kshara-sootra in management of fistula-in-ano. Indi J. Med. Res. (B), 177-185, 1994.

7. Ghanekar BG, Susruta Samhita, Sutra sthana 11, ML Publication, New Delhi,1998

8. Srinivasan K (2007). Black pepper and its pungent principle-piperine: A review of diverse physiological effects Critical Rev. Food Nut. 47: 735-748. 
9. Mathews VH, Rao PS (1984). In vitro responses in black pepper (Piper nigrum). Curr. Sci. 53: 183-186.

10. Warrier PK, Nambiar VPK, Ramankulty C, Indian Medicinal Plants a compendium of 500 species, ed. $1^{\text {st }}$, Vol. I, Orient Longman Private Limited, Hyderabad, 2006.

11. Kirtikar KR, Basu BD, Indian Medicinal Plants, ed. $2^{\text {nd }}$, Vol. I-IV, Bishen Singh Mahendra Pal Singh, Dehradun, 1935.

12. Yoganarasimhan SN, Chelladuri V, Medicinal Plants of India, Vol. I, Cyber Media, Bangalore, 2000.

13. Philip VJ, Dominic J, Triggs GS, Dickinson NM (1992). Micropropagation of black pepper (Piper nigrum L.) through shoot tip cultures. Plant Cell Rep. 12: 41-44.

14. Kay DE (1970). The production and marketing of Pepper. Trop Sci. 12: 201-218.

15. Tripathi AK, Jain DC, Kumar S (1996). Secondary metabolites and their biological and medical activities of Piper species plants.J. Med. Aromatic Plant Sci. 18: 302-321.

16. Scott IM, Jensen HR, Philogene BJR, Arnason JT (2008). A review of Piper spp. (Piperaceae) Phytochemistry, insecticidal activity and mode of action. Phytochem. Rev. 7: 65-75.

17. Lupina T, Cripps H (1987). The photo isomers of Piperine. J. Anal. Chem. 70: 112-113.

18. Umit A, Ilhan Kadir, Akgun KO (2009). Antifungal activity of aqueous extracts of spices against bean rust (Uromyces appendiculatus). Allelopathy J. 24: 0973-1046.

19. Boff MIC, Sartoari DV, Bogo A (2006). Effect of extracts of Piper nigrum L. on the bean weevil, Acanthoscelides obtectus (Say). Revista Brasileria de Armazenamentho 31: 17-22.

20. Santra M, Santra DK, Rao VS, Taware SP, Tamhankar SA (2005). Inheritance of _-carotene concentration in durum wheat (Triticum turgidum L.ssp.durum). Eucalypta 144: 215-221.

21. Jayalekshmy A, Menon AN, Padmakumari KP (2003). Essential oil composition of four major cultivars of black pepper (Piper nigrum L.). J. Essential Oil Res. 15: 155-157.

22. Dorman HJ, Deans S (2000). Antimicrobial agents from plants; Antibacterial activity of plant volatile oils. J. Appl. Microbiol. 88: 308- 316.

23. El-Hamas R, Idaomar M, AlonsoMoraga A, Munoz Serra A (2003). Antimutagenic properties of bell and black peppers. Food Chem Toxicol. 41: 41-47.

24. Gulcin I (2005). The antioxidant and radical scavenging activities of black pepper (Piper nigrum) seeds. Int. J. Food Sci. Nutr. 56: 491- 499.

25. Saxena RK, Venkaiah P, Anitha L, Venu, Raghunath M (2007). Antioxidant activity of commonly consumed plant foods of India Contribution of their phenolics contents. Int. J. Food Sci. Nut. 58: 250-260.

26. Sunila ES, Kuttan G (2004). Immunomodulatory and Antitumor activity of Piper longum Linn. And Piperine. J. Ethnopharmacol. 90: 339346.

27. Lee SA, Hong SS, Han XH, Hwang JS, Oh GJ, Lee KS, Lee MK, Hwang BY, Ro JS (2005). Piperine from the fruits of Piper longum with inhibitory effect on monoamine oxidase and anyidepressant-like activity. Chem. Pharm. Bull. (Tokyo) 53: 832.-835.

28. Pathak N, Khandlewal S (2007). Cytoprotective and immunomodulating properties of Piperine on murine splinocytes: an in vitro study. Eur. J. Pharmacol. 576: 160.

29. Pradeep CR, Kuttan G (2002). Effect of Piperine on the inhibition of lung metastasis induced by B16F-10 
melanoma cells in mice. Clin. Exp. Metastasis 19: 703.

30. Panda S, Kar A (2003). Piperine lowers the serum concentration of thyroid hormones, glucose and hepatic 5D activity in adult male mice. Horm. Metab. Res. 35: 523.

31. Koul IB, Kapil A (1993). Evaluation of the liver protective potential of Piperine, an active principle of black and long peppers. Planta Med. 59: 413.

32. Pathak N, Khandelwal S (2009). Immunomomodulatory role of Piperine in cadmium induced thymic atrophy and splenomegaly in mice. Env. Toxic. Pharma. 28: 52-60.

33. Bajad S, Bedi KL, Singla AK, Johri RK (2001). Antidiarrhoeal activity of Piperine in mice. Planta Med. 67: 284287.

34. Ravindran PN, Babu KN, Sasikumar B, Krishnamurthy KS (2000). Botany and Crop improvement of Black Pepper. In: Black pepper (Piper nigrum L).. Medicinal aromatic plants-Industrial Profiles, Harwood Academic Publishers. Ravindran, P. N. (Ed). Amsterdam. The Netherlands pp. 32-142.

35. Parmar VS, Jain SC, Bisht KS, Jain R, Taneja P, Jha A, Tyagi OD, Prasad AK, Wengel J, Olsen CE, Boll PM (1997). Phytochemistry of the genus Piper. Phytochem. 46: 597-673.

36. Kumar S, Singhal V, Roshan R, Sharma A, Rembhotkar GW, Ghosh B (2007). Piperine inhibits TNFinduced adhesion of neutrophils to endothelial monolayer through suppression of NF-к and ІкB kinase activation. Eur. J. Pharmacol. 575: 177-186.

37. Mishra RK, Singh SK (2009). Antispermatogenic and antifertility effects of fruits of Piper nigrum L. in mice 47: 706-714.

38. Kiuchi F, Nakamura N, Tsuda Y, Kaoru K, Yoshimura H (1988). Studies on crude drugs effective on visceral: Isolation and identification of larvicidal principles in piper Chem.Pharma. Bull. 36: 2452.

39. Miyakado M, Nakayama I, Yoshioka $\mathrm{H}$ (1980). Insecticidal joint action of pipercide and co- occurring compounds isolated from Piper nigrum L. Agric. Biol. Chem. 44: 1701-1703.

40. Bandyopadhyay V, Narayan S, Variyar PS (1990). Phenolics of green pepper berries (Piper nigrum L.) J. Agric. Food Chem. 38: 1696- 1699.

41. Stohr JR, Xiao PG, Bauer R (2001). Constituents of Chinese Piper species and their inhibitory activity on prostaglandin and leukotriene biosynthesis in vitro. J. Enthnopharma. 75: 133-139.

42. Bano G, Raina RK, Zutshi U, Bedi KL, Johri RK, Sharma SC (1991). Effect of Piperine on bioavailibity and pharmacokinetics propranolol and theophylline in healthy volunteers. Eur. J. Clin. Pharmacol. 41: 615-617.

43. Nakatani $N$, Inatani $R$, Fuwa $H$ (1980). Structures and syntheses of two phenolic amides from Piper nigrum L. Agric. Biol. Chem. 44: 2831- 2836

44. Orjala J, Erdelmeier CAJ, Wright AD, Rali T, Sticher O (1993). Two chromenes and a prenylated benzoic acid derivative from Piper aduncum. Pytochemistry 34: 813-818.

45. Dev S, Koul O (1997). Insecticides of natural origin Harwood Academic Publishers Amsterdam p. 365.

46. Pino JA, Aguero J, Fuentes V (2003) Chemical composition of the aerial parts of Piper nigrum L. from Cuba. J. Essential Oil Res. 15: 209-210.

47. Ames BN (1983). Dietary carcinogens and anticarcinogens: Oxygen radicals and degenerative diseases Sci. 221: 1256-1264.

48. Eisei Indonesia PT., Medicinal Herb Index in Indonesia, 1995. 2nd ed.; PT Eisei Indonesia, Jakarta. 
49. Satroamidjojo, 2001. Obat Asli Indonesia, Dian Rakyat, Jakarta

50. Usia, T., Watabe, T., Kadota, S., Tezuka, Y., 2005a. Potent cyp3A4 inhibitory constituents of Piper cubeba. Journal of Natural Products, 68, 64-68.

51. Usia, T., Watabe, T., Kadota, S., Tezuka, Y., 2005b. Metabolitecytochrome P450 complex formation by methylenedioxyphenyl lignans of Piper cubeba: mechanism-based inhibition. Life Sciences, 76, 23812391.

52. Parmar, V.S., Jain, S.C., Bisht, K.S., Jain, R., Taneja, P., Jha, A., Tyagi, O.D., Prasad, A.K., Wengel, J., Olsen, C.E., Boll, P.M., 1997. Phytochemistry of the genus Piper. Phytochemistry, 46, 597-673.

53. Prabhu, B.R., Mulchandani, N.B., 1985. Lignans from Piper cubeba. Phytochemistry, 24, 329-331.

54. Badheka, L.P., Prabhu, B.R., Mulchandani, N.B., 1986. Dibenzylbutyrolactone lignans from Piper cubeba. Phytochemistry, 25, 487-489

55. Badheka, L.P., Prabhu, B.R., Mulchandani, N.B., 1987. Lignans of Piper cubeba. Phytochemistry, 26, 2033-2036.

56. Koul, J.L., Koul, S.K., Taneja, S.C., Dhar, K.L., 1996. Oxygenated cyclohexanes from Piper cubeba. Phytochemistry, 41, 1097-1099.

57. Harmatha, J., Nawrot, J., 2002. Insect feeding deterrent activity of lignans and related phenylpropanoids with a methylenedioxyphenyl (Piperonyl) structure moiety. Entomologia Experimentalis et Applicata, 104, 5160.

58. Da Silva, R., De Souza, G.H.B., Da Silva, A.A., De Souza, V.A., Pereira, A.C., Royo, V.D., Silva, M.L.A.E., Donate, P.M., Araujo, A.L.S.D., Carvalho, J.C.T., Bastos, J.K., 2005. Synthesis and biological activity evaluation of lignan lactones derived from (-)-cubebin. Bioorganic \& Medicinal Chemistry Letters, 15, 1033-1037.

59. Bastos, J.K., Carvalho, J.C.T., de Souza, G.H.B., Pedrazzi, A.H.P., Sarti, S.J., 2001. Anti-inflammatory activity of cubebin, a lignan from the leaves of Zanthoxyllum naranjillo Griseb. Journal of Ethnopharmacology, 75, 279-282.

60. Borsato, M.L.C., Grael, C.F.F., Souza, G.E.P., Lopes, N.P., 2000. Analgesic activity of the lignans from Lychnophora ericoides. Phytochemistry, 55, 809-813.

61. De Souza, V.A., Da Silva, R., Pereira, A.C., Royo, V.D., Saraiva, J., Montanheiro, M., De Souza, G.H.B., Da Silva, A.A., Grando, M.D., Donate, P.M., Bastos, J.K., Albuquerque, S., Silva, M.L.A.E., 2005. Trypanocidal activity of (-)cubebin derivatives against free amastigote forms of Trypanosoma cruzi. Bioorganic \& Medicinal Chemistry Letters. 15, 303-307.

62. Choi, E.M., Hwang, J.K., 2005. Effect of some medicinal plants on plasma antioxidant system and lipid levels in rats. Phytotherapy Research, 19, 382386

63. Choi, E.M., Hwang, J.K., 2005. Screening of Indonesian medicinal plants for inhibitor activity on nitric oxide production of RAW264.7 cells and antioxidant activity. Fitoterapia, 76, 194-203.

64. Hussein, G., Miyashiro, H., Nakamura, N., Hattori, M., Kakiuchi, N., Shimotohno, K., 2000. Inhibitory effects of Sudanese medicinal plant extracts on hepatitis $\mathrm{C}$ virus (HCV) protease. Phytotherapy research, 14, 510-516.

65. Amit A, Saxena VS, Pratibha N, D'Souza P, Banchi M, Bagchi D and Stohs SJ, Mast cell stabilization, lipoxygenase inhibition, Lyaluronidase inhibition, antihistaminic and anti-spasmodic 
activities of Aller-7, a novel botanical formulation for allergic rhinitis, Drugs Exp Clin Res, 2003, 29 (3), 107-115.

66. Anshuman PS, Sing KP and Aasra $\mathrm{KG}$, Effect of Vardhaman pippali (Piper

longum) on patients with respiratory disorders, Sachitra Ayurv, 1984, 37 (1), 47-49.

67. Bai YF and $\mathrm{Xu} \mathrm{H}$, Protective action of Piperine against experimental gastric ulcer, Acta Pharmacol Sin, 2000, 21(4), 357-359.

68. Banerjee NS, Manoj P and Das MR, Male sex associated RAPD markers in Piper longum Linn., Curr Sci, 1999, 77(5), 693-695.

69. Chatterjee S, Bronchodilatory and anti-allergic effect of Pulmoflex-A proprietary herbal formulation, Indian J Physiol Pharmacol, 1999, 43(3), 486-490.

70. Dahanukar SA, Karandikar SM and Desai M, Efficacy of Piper longum in childhood asthma, Indian Drugs, 1984, 21(9), 384-388.

71. Kholkute SD, Kekare MB and Munshi SR, Antifertility effects of the fruits of Piper longum in female rats, Indian J Exp Biol, 1979, 17, (3), 289-290.
72. Koul IB and Kapil A, Evaluation of the liver protective potential of Piperine, an active principle of black pepper and long pepper, Planta Med, 1993, 59(5), 413-417.

73. Kurup PNV, Ramdas VNK and Joshi P, Handbook of Medicinal Plants, New Delhi, 1979, 166.

74. Neelam and Krishnaswamy Kamala, Nutritive value of Pepper, In: Pepper market review, National Institute of Nutrition, Hyderabad, May, 2001, 1-5.

75. Sivarajan VV and Balachandran Indira, Ayurvedic drugs and their plant sources, Oxford and IBH Publishing Co.Pvt.Ltd, New Delhi, 1994, 374-376.

76. Sumy Oommen, Ved DK and Krishnan R, Tropical Indian Medicinal Plants, propagation methods, 2000, 268-269.

77. Sunila ES and Kuttan G, Immunomodulatory and anti-tumour activities of Piper longum Linn. and piperine, J Ethnopharmcol, 2004, 90(2-3), 339-346.

78. Sharma SK, Sharma KR, Singh K, Kshara Sutra Therapy in Fistula- in ano and other Ano- Rectal Disorders, R.A.V. Publication, New Delhi, 1995. 